\title{
An Irrigation Scheduling Model for Turnip Greens
}

\author{
Eric H. Simonne ${ }^{1}$, Doyle A. Smittle ${ }^{2}$, and Harry A. Mills \\ Department of Horticulture, Coastal Plain Experiment Station, Tifton, GA 31793
}

Additional index words. soil water tension, pan evaporation, leafy vegetable, Brassica rapa, nitrogen fertilization

\begin{abstract}
An irrigation scheduling model for turnip (Brassica rapa $\mathrm{L}$.) was validated using a line-source irrigation system in a 2-year field trial. The model used a water balance, a variable root length, and a crop factor function of plant age (i). Evapotranspiration was computed daily as class A pan evaporation times a crop factor $[\mathrm{CF}(\mathbf{i})=\mathbf{0 . 3 6 5}+\mathbf{0 . 0 1 5 4} \mathbf{- 0 . 0 0 0 1 1 i}]$. Irrigation according to the model maintained soil water tension at $<25 \mathrm{kPa}$ at a $30-\mathrm{cm}$ depth. When rainfall amounts were less than water use, leaf yields responded quadratically to irrigation rates, from $0 \%$ to $160 \%$ of the model rate, and the highest leaf yield with the lowest water applications corresponded to the model rate. Therefore, this model could replace the "feel or see" methods commonly used for scheduling irrigation of leafy vegetables grown in the southeastern United States.
\end{abstract}

Turnip has a high nutritional value (Salunkhe et al., 1973) and is widely grown under irrigation and high $\mathrm{N}$ fertilization in the southeastern United States as a fresh-market and processinggreens crop. The most widely used methods for scheduling irrigation of leafy greens are the "feel" or "see" methods, which consist of applying $19 \mathrm{~mm}$ of water when the soil looks dry or when plants wilt. Because water applications are not adjusted to weather condition or crop age, excessive water may leach essential nutrients, or water stress may reduce yields.

Information on the water requirements of leafy vegetables is limited, and few irrigation scheduling methods for greens crops are available. Water use by red cabbages (Brassica oleracea L.) (Nieuwhof, 1969) or water applications of $7.5 \mathrm{~mm}$ every 10 days to spinach (Spinacia oleracea L.) (Breimer, 1983) cannot be used for scheduling irrigation without adjustments for weather conditions. McSay and Moore (1980) developed regression equations based on cumulative evaporation from Bellani plates to predict soil water tension (SWT) and schedule irrigation of lettuce (Lactuca sativa L.). Although water applications could be reduced by $66 \%$ without affecting yields, this method was not practical, and rainfall amounts less than cumulative water deficit were neglected. Irrigating turnip to field capacity when plants wilted produced $41 \%$ higher leaf yields than nonirrigated turnip (del Valle et al., 1965). Mustard (Brassica juncea L.) and turnip produced higher leaf yields if irrigated at $25 \mathrm{kPa}$ rather than at 50 or $75 \mathrm{kPa}$ SWT (Smittle et al., 1992b). Water use rates increased quadratically with crop age and were higher with irrigation at $25 \mathrm{kPa}$ than at 50 or $75 \mathrm{kPa}$ SWT.

Class A pan evaporation $\left(\mathrm{E}_{\mathrm{p}}\right)$ can estimate evapotranspiration (ET) if a crop factor $\left(\mathrm{CF}=\mathrm{ET} / \mathrm{E}_{\mathrm{p}}\right)$ is used to adjust $\mathrm{E}_{\mathrm{p}}$ (Jensen and Middleton, 1970). Irrigation scheduling methods using the water balance technique (Stansell and Smittle, 1980; Stegeman et al., 1980), in which ET was estimated from $E_{p}$, and CF was a function of plant age (i), were developed for snap bean (Phaseolus vulgaris L.) (Smittle et al., 1990) and summer squash (Cucurbita pepo L.) (Smittle et al., 1992a). Smittle et al. (1992b) developed a CF(i) that estimated ET by turnip grown in the spring.

Although turnip leaf yields were responsive to $\mathrm{N}$ fertilization

Received for publication 24 July 1992. Accepted for publication 19 Feb. 1993. Supported by state and Hatch Act funds allocated to the Georgia agricultural experiment stations. The cost of publishing this paper was defrayed in part by the payment of page charges. Under postal regulations, this paper therefore must be hereby marked advertisement solely to indicate this fact.

${ }^{1}$ Current address: Micro-Macro International, 183 Paradise Boulevard, Suite 108, Athens, GA 30607.

${ }^{2}$ To whom reprint requests should be addressed. (del Valle et al., 1965; McFerran et al., 1963), N source effects on leaf yields were variable. Leaf yields with $\mathrm{NaNO}_{3}$ and $\mathrm{NH}_{4} \mathrm{NO}_{3}$ were similar, but both of these $\mathrm{N}$ sources produced higher yields than $\left(\mathrm{NH}_{4}\right)_{2} \mathrm{SO}_{4}$ (del Valle and Harmon, 1970). Other studies (Bowers and Vose, 1959; Bowers et al., 1962) reported higher leaf yields with $\mathrm{NaNO}_{3}$ than with $\mathrm{NH}_{4} \mathrm{NO}_{3}$. Brantley (1960) found that $\mathrm{NH}_{4} \mathrm{NO}_{3}, \mathrm{NaNO}_{3}$, and $\left(\mathrm{NH}_{4}\right)_{2} \mathrm{SO}_{4}$ were equally effective in influencing the leaf yields of fall-grown turnip. Although sodium dispersed clays and altered soil structure (Tan, 1982), $\mathrm{NaNO}_{3}$ is the $\mathrm{N}$ source recommended for turnip (Adams, 1991).

This paper presents the field validation of an irrigation scheduling model for turnip grown in the spring. Because $\mathrm{N}$ form influenced the yields of most vegetables (Barker and Mills, 1980), and because the $\mathrm{N}$ source that maximizes turnip leaf yield has not been determined, the model was validated using the most commonly used $\mathrm{N}$ fertilizers.

\section{Materials and methods}

Model development. The irrigation scheduling model used the water balance method (Stegeman et al., 1980) which consisted of computing daily use $\left(\mathrm{d}_{\mathrm{i}}, \mathrm{mm}\right)$ as:

$$
d_{i}=E T_{i}-R_{i}-I_{i}
$$

where ET was evapotranspiration ( $\mathrm{mm}), \mathrm{R}$ was rainfall $(\mathrm{mm})$, and I was irrigation $(\mathrm{mm})$; cumulative soil water deficit on day $i\left(D_{i}\right.$, $\mathrm{mm})$ as:

$$
D_{i}=D_{i-1}+d_{i}
$$

where $D_{i-1}$, was the cumulative soil water deficit on day $i-1$; and the daily water balance as:

$$
A_{i}=D_{i-1}+\left(E T_{i}-R_{i}-I_{i}\right)
$$

where $A_{i}$ was the allowable water use ( $\left.\mathrm{mm}\right)$.

The proposed model for spring-grown turnips was:

$$
12.7 \times(i-3) \times 0.5 \mathrm{ASW}=\mathrm{D}_{\mathrm{i}-1}+\left(\mathrm{ET}_{\mathrm{i}}-\mathrm{R}_{\mathrm{i}}-\mathrm{I}_{\mathrm{i}}\right)[\mathrm{Eq} .4]
$$

where $\mathrm{i}$ was days from planting, and ASW was the available soil

Abbreviations: Ai, allowable water use; ASW, available soil water; $\mathrm{CF}$, crop factor; di, daily water use; Di, cumulative soil water deficit; DAP, days after planting; Ep, class A pan evaporation; ET, evapotranspiration; i, plant age; I, irrigation; R, rainfall; SWT, soil water tension. 
water (mm water/mm soil).

$\mathrm{A}_{\mathrm{i}}$ was computed as $12.7 \times(\mathrm{i}-3) \times 0.5 \mathrm{ASW}$ and depended on effective rooting depth, soil water retention characteristics, crop sensitivity to water stress, and plant age. The model assumed a 6.7$\mathrm{mm}$ seeding depth, 3 days for radicle emergence, and a 12.7$\mathrm{mm} \cdot \mathrm{day}^{-1}$ root elongation (Hansen et al., 1980). A maximum rooting depth of $300 \mathrm{~mm}$ was used because hard pans or low soil $\mathrm{pH}$ restrict root depth of most vegetable crops in the southeastern United States. The maximum rooting depth may be greater in areas where soil conditions are not restrictive. The ASW for a Tifton loamy sand soil (plinthitic Paleudult of a fine loamy, siliceous, thermic family) was $0.1 \mathrm{~mm}$ of water/mm of soil depth. A $50 \%$ depletion of ASW was allowed.

ET was computed as class A pan evaporation $\left(\mathrm{E}_{\mathrm{p}}, \mathrm{mm}\right) \times \mathrm{CF}(\mathrm{i})$, where $\mathrm{CF}(\mathrm{i})=0.365+0.0154 \mathrm{i}-0.0001 \mathrm{li}^{2}$ (Smittle et al., 1992b).

Replacing $12.7 \times 0.5$ by 6.35 in the calculation of $A_{i}$ would be numerically correct; however, it is easier to adapt the model to different growing conditions when each term appears individually. Also, solving Eqs. 3 or 4 for the unknown I would result in negative irrigations on the dates no irrigation was scheduled.

For record keeping, a tabular format (Smittle and Dickens, 1992) with column headings of age, rooting depth, date, pan evaporation, crop factor, daily water use, cumulative water use, allowable water use, rainfall, and irrigation was used to compute soil water status (Table 1). Rooting depth, crop factor, allowable water use, and cumulative water use were computed by days after planting (DAP). To operate the model, the date and daily pan evaporation were entered. Daily water use and cumulative water use were computed (Eq. 1 and 2), and the decision whether to irrigate was made daily.

When cumulative water use $\left(\mathrm{D}_{\mathrm{i}}\right)$ approximated the allowable water use $\left(\mathrm{A}_{\mathrm{i}}\right)$, an irrigation amount (I) equal to the cumulative water use was applied. The cumulative water use became 0 following irrigation or when rainfall was equal to or greater than the value for allowable water use. Only water amounts equal to or less than cumulated water deficit could be stored in the soil. Rain amounts in excess of soil water deficit at the time of the rain were considered lost, and upward water movements from the water table were considered negligible.

Model validation. Model validation consisted of scheduling irrigation according to the model and applying increasing water amounts across the field (Smittle et al.; 1990; 1992a). The model was acceptable if SWT remained $\leq 25 \mathrm{kPa}$, and leaf yields were highest in areas receiving the water amounts predicted by the model.

Rye (Secale cereale L.) cover crop was incorporated $15 \mathrm{~cm}$ deep with a disc harrow before moldboard plowing to 30-cm depth in 1990 and 1991. We incorporated $1121 \mathrm{~kg}$ preplant fertilizer/ha $(5 \mathrm{~N}-4.4 \mathrm{P}-12.4 \mathrm{~K}) 15 \mathrm{~cm}$ deep with a rotary tiller. 'Shogoin' turnip was direct-seeded in four rows spaced $30.5 \mathrm{~cm}$ apart on 1.5 -m-wide beds on 5 Mar. 1990 and 11 Mar. 1991. Each planter sowed twin rows $38 \mathrm{~mm}$ apart with seeds $20 \mathrm{~mm}$ apart. Plant population was $\approx 1$ million plants/ha. Ammoniated polyphosphate fertilizer $(10 \mathrm{~N}$ 15P) was banded at $204 \mathrm{~kg} \cdot \mathrm{ha}^{-1}$, and dimethyl-tetrachloroterephtalate herbicide (Dacthal) was broadcast at $9 \mathrm{~kg} \cdot \mathrm{ha}^{-1}$ after seeding. An irrigation of $19 \mathrm{~mm}$ on 9 Mar. 1990 and $13 \mathrm{~mm}$ on 12 Mar. 1991 over the entire field incorporated herbicide and fertilizers and ensured uniform germination. Pest control measures were those recommended for turnip production in Georgia (Brown, 1989).

The model was tested with several rates of $\mathrm{N}$ applied as a sidedressing. In 1990, 50, 62, and $73 \mathrm{~kg} \mathrm{~N} / \mathrm{ha}$, corresponding respectively to $80 \%, 100 \%$, and $120 \%$ of the median recommended range for Georgia (Plank, 1989), were applied as $\mathrm{NaNO}_{3}$ $(16 \% \mathrm{~N})$. In 1991, $62 \mathrm{~kg} \mathrm{~N} /$ ha was applied as $\mathrm{NaNO}_{3}(16 \% \mathrm{~N})$, $\mathrm{NH}_{4} \mathrm{NO}_{3}(34 \% \mathrm{~N})$, or $\mathrm{Ca}\left(\mathrm{NO}_{3}\right)_{2}(15.5 \% \mathrm{~N})$. Sidedressed fertilizers were applied 3 weeks after seeding and again after harvesting the first crops.

A line-source irrigation system (Hanks et al., 1976) consisting of a single line of sprinklers spaced $6.1 \mathrm{~m}$ apart provided uniform water distribution parallel to the irrigation line and a water gradient perpendicular to the irrigation line. Preliminary tests showed that in the absence of wind, the gradient was uniform. The irrigation line was placed on a central guard bed and depths of water application to each bed on both sides of the irrigation line were measured at each irrigation. The line source created seven irrigation rates, decreasing from rate 1 to 7 . The amounts and dates of application of irrigation rate 3 were determined by the irrigation scheduling model (model rate). Rates 2 and 1 represented progressively greater water applications, and rates 4, 5, 6, and 7 represented progressively smaller ones than the model rate. The water regime of irrigation rate 7 corresponded to a nonirrigated crop.

Table 1. Irrigation scheduling model for turnip ${ }^{2}: 12.7 \times(i-3) \times 0.5 \mathrm{ASW}=\mathrm{D}_{\mathrm{i}-1}+\left[\mathrm{E}_{\mathrm{p}}\left(0.365+0.0154 \mathrm{i}-0.00011 \mathrm{i}^{2}\right)-\mathrm{R}-\mathrm{I}_{\mathrm{i}}{ }^{\mathrm{y}}\right.$

\begin{tabular}{|c|c|c|c|c|c|c|c|c|c|}
\hline $\begin{array}{l}\text { Age } \\
\left(^{D A P}\right)^{x}\end{array}$ & $\begin{array}{c}\text { Rooting } \\
\text { depth } \\
(\mathrm{mm})\end{array}$ & $\begin{array}{c}\text { Date } \\
(1990)\end{array}$ & $\begin{array}{l}\text { Class A pan } \\
\text { evaporation } \\
(\mathrm{mm})\end{array}$ & $\begin{array}{l}\text { Crop } \\
\text { factor }\end{array}$ & $\begin{array}{l}\text { Daily } \\
\text { use } \\
(\mathrm{mm})\end{array}$ & $\begin{array}{l}\text { Rain } \\
(\mathrm{mm})\end{array}$ & $\begin{array}{l}\text { Cumulative } \\
\text { water use } \\
(\mathrm{mm})\end{array}$ & $\begin{array}{c}\text { Allowable } \\
\text { water use } \\
(\mathrm{mm})\end{array}$ & $\begin{array}{l}\text { Irrigation } \\
\text { (mm) }\end{array}$ \\
\hline 21 & 216 & 26 Mar. & 4.6 & 0.64 & 3.0 & & 3.0 & 10.9 & \\
\hline 22 & 229 & 27 Mar. & 6.4 & 0.65 & 4.2 & & 7.2 & 11.4 & \\
\hline 23 & 241 & $28 \mathrm{Mar}$. & 4.8 & 0.66 & 3.2 & & 10.4 & 12.2 & \\
\hline 24 & 254 & 29 Mar. & 2.5 & 0.67 & 1.7 & & 12.0 & 12.7 & 12.0 \\
\hline 25 & 267 & 30 Mar. & 3.6 & 0.68 & 2.5 & 1.0 & 1.5 & 13.5 & \\
\hline 26 & 279 & 31 Mar. & 6.9 & 0.69 & 4.7 & 22.8 & 0.0 & 14.0 & \\
\hline 27 & 292 & 1 Apr. & 3.1 & 0.70 & 2.2 & 1.0 & 1.2 & 14.7 & \\
\hline 28 & 305 & 2 Apr. & 4.1 & 0.71 & 2.9 & 0.3 & 2.8 & 15.3 & \\
\hline 29 & 305 & 3 Apr. & 3.6 & 0.72 & 2.6 & 0.7 & 4.7 & 15.3 & \\
\hline
\end{tabular}

${ }^{\mathrm{z}}$ Turnip grown in the spring as a greens crop on a Tifton loamy sand soil.

${ }^{y} \mathrm{ASW}$ is available soil water $(0.1 \mathrm{~mm}$ water per $\mathrm{mm}$ soil $), D_{i-1}$ is cumulative soil water deficit $(\mathrm{mm}), E_{p}$ is class $A$ pan evaporation $(\mathrm{mm}), \mathrm{R}$ is rainfall $(\mathrm{mm})$, and $\mathrm{I}$ is irrigation $(\mathrm{mm})$. To operate the model, values for rooting depth $[12.7 \times(\mathrm{i}-3)]$, $\operatorname{crop}$ factor $(0.0365$ $+0.0154 \mathrm{i}-0.00011 \mathrm{i}^{2}$ ), and allowable water use (rooting depth $\times 0.5 \mathrm{ASW}$ ) are calculated as a function of plant age (i). Date and $E_{p}$ are recorded. $E_{p}$ is multiplied by the crop factor to estimate daily water usc $\left(d_{i}\right)$, and $d_{i}$ is added to $D_{i-1}$. $R$ is subtracted from $D_{i}$. Irrigation, in the amount of cumulative water use, is applied when cumulative water use approximates allowable water use. ${ }^{x} \mathrm{DAP}$ is days after planting. 
Table 2. Irrigation rates, water applications, irrigation gradient, and total rainfall of four crops of 'Shogoin" turnip during Spring 1990 (crops 1 and 2) and 1991 (crops 3 and 4).

\begin{tabular}{|c|c|c|c|c|c|c|c|c|}
\hline \multirow{2}{*}{$\begin{array}{l}\text { Irrigation } \\
\text { rate }^{z}\end{array}$} & \multicolumn{8}{|c|}{ Crop } \\
\hline & 1 & 2 & 3 & 4 & 1 & 2 & 3 & 4 \\
\hline & \multicolumn{4}{|c|}{ Water applied $(\mathrm{mm})$} & \multicolumn{4}{|c|}{ Water gradient (\% Model) ${ }^{y}$} \\
\hline 1 & 982 & 1483 & 512 & 316 & 166 & 163 & 147 & 136 \\
\hline 2 & 779 & 1179 & 469 & 289 & 131 & 130 & 132 & 125 \\
\hline 3 & 591 & 910 & 348 & 232 & 100 & 100 & 100 & 100 \\
\hline 4 & 460 & 708 & 279 & 191 & 79 & 78 & 80 & 82 \\
\hline 5 & 368 & 538 & 211 & 151 & 62 & 59 & 61 & 65 \\
\hline 6 & 206 & 347 & 105 & 100 & 35 & 38 & 30 & 43 \\
\hline 7 & 6 & 12 & 0 & 0 & 1 & 1 & 0 & 0 \\
\hline Rainfall (mm) & 88 & 10 & 107 & 133 & & & & \\
\hline
\end{tabular}

${ }^{\mathrm{z}}$ All plots received an additional irrigation of $19 \mathrm{~mm}$ in 1990 and $12.7 \mathrm{~mm}$ in 1991 after seeding. Irrigation rate 3 was determined by the irrigation scheduling model. The irrigation gradient was created by a line-source irrigation system.

y Irrigation gradient calculated as percent of the model rate.

Gypsum resistance blocks were installed at $15 \mathrm{~cm}$ and $30-\mathrm{cm}$ depths in the center of inside rows after seedling emergence for SWT measurements. SWT was determined before each irrigation with an ammeter (KS-2; Delmhorst Instruments Co., Boonton, N.J.). Class A pan evaporation and rainfall were recorded at a \#2 U.S. National Weather Service station $300 \mathrm{~m}$ from the field.

Turnip leaf yields were recorded by harvesting the leaves from $1.5 \mathrm{~m}^{2}$ in the center of each subplot. The leaves were cut 4 to $5 \mathrm{~cm}$ above the soil twice each season as done in commercial production. In 1990, the first harvest (crop 1) occurred 36 DAP, and the second harvest (crop 2) 56 DAP. In 1991, the first harvest (crop 3) was made 37 DAP, and the second harvest (crop 4) 63 DAP.

Treatments were arranged in a split-plot design with two replications on each side of the irrigation line. Main plots $(15 \times$ $10.5 \mathrm{~m})$ were $\mathrm{N}$ rates in 1990 and $\mathrm{N}$ sources in 1991. Subplots (1.5 $\times 15 \mathrm{~m}$ ) were irrigation rates. Analysis of variance determined significance of main effects and interactions. Regression analysis by $\mathrm{N}$ fertilization determined mean yield response to irrigation (SAS, 1987).

\section{Results and Discussion}

Responses of the two crops in 1990 and the two crops in 1991 are discussed as four separate crops, because all the foliage above $5-\mathrm{cm}$ height was removed at harvest, irrigation scheduling was based on plant age, and weather conditions were different. In addition, the year effect was not significant $(P=0.10)$ for SWT but was significant $(P<0.01)$ for leaf yield, while the crop effect was significant $(P<0.01)$ for SWT and leaf yield.

Rainfall during the four crops differed by amount and distribution. Total rainfall was $88 \mathrm{~mm}$ during the 36-days growth of turnip for crop 1,10 mm during the 20-days regrowth for crop 2,107 mm during the 37-day growth for crop 3, and $133 \mathrm{~mm}$ during the 26-day regrowth for crop 4 . The $4,2,6$, and 5 rainfalls during crops 1,2 , 3 , and 4, respectively, and exceeded the respective cumulative soil water deficit by $67,0,65$, and $80 \mathrm{~mm}$. Excessive rainfall results in lateral movement, runoff, or deep percolation of the water in excess of field-capacity. Lateral water movement in the profile reduces the accuracy of water balance models in small plots, but is of little practical concern, because irrigation is not applied when rainfall meets crop needs and because irrigation amounts do not exceed soil water deficits. However, deep percolation from excessive rainfall can leach mobile nutrients in small or large fields.

In 1990, total irrigation for plots receiving the model rate was $591 \mathrm{~mm}$ applied on six dates for crop 1, and $910 \mathrm{~mm}$ applied on five dates for crop 2. In 1991, total irrigation was $348 \mathrm{~mm}$ applied on five dates for crop 3 and, $232 \mathrm{~mm}$ applied on two dates for crop 4 . The irrigation gradient created by the line source ranged from $0 \%$ to $166 \%$ of the model rate (Table 2).

The SWT differences at $15-\mathrm{cm}$ and $30-\mathrm{cm}$ depths before irrigation were not significant $(P=0.90)$; thus, data for both depths were pooled. This suggested that the model allowed the control of soil water status in the top $30 \mathrm{~cm}$ of soil.

The SWT of plots receiving irrigation rate 3 was $>25 \mathrm{kPa}$ only on 53 DAP in 1990 and on 24 and 34 DAP in 1991. In 1990, the cumulative deficit on 52 DAP was $12.7 \mathrm{~mm}$. Because the allowable use was $15.3 \mathrm{~mm}$, irrigation was delayed until the next day. Water

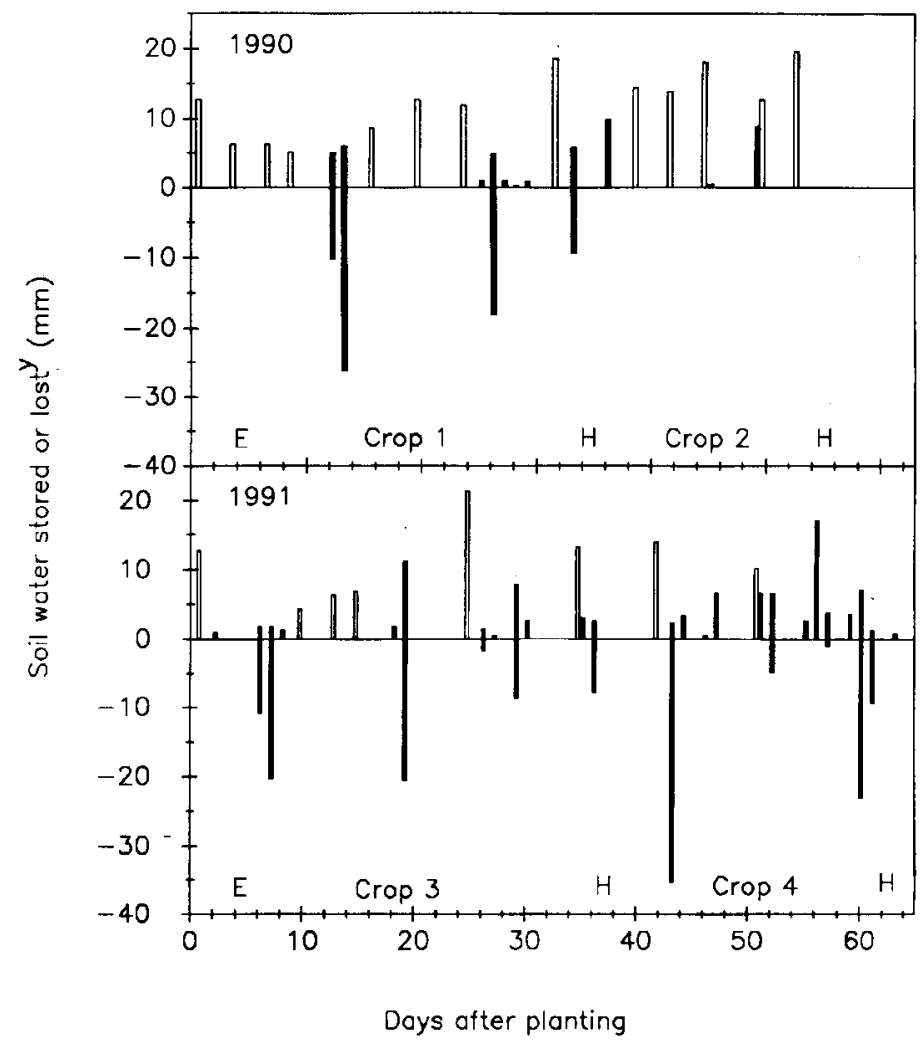

Fig. 1. Rainfalls (solid bars) and irrigations (open bars) during turnip grown in Spring 1990 and 1991. Positive and negative amounts of water represent water amounts considered as stored or lost, respectively. Rainfall amounts exceeding soil water deficit at the time of the occurrence are considered lost by runoff or deep percolation. $\mathrm{E}$ is emergence, and $\mathrm{H}$ represent harvests. 
use of $6.6 \mathrm{~mm}$ on 53 DAP resulted in a cumulative deficit of 19.3 $\mathrm{mm}$, which exceeded the $15.5-\mathrm{mm}$ allowable water deficit and produced a SWT of $35 \mathrm{kPa}$. In 1991, winds on 23 and 24 DAP delayed the irrigation scheduled for 23 DAP. At irrigation, the 21.4-mm cumulative deficit exceeded the 13.5-mm allowed use and SWT reached $46 \mathrm{kPa}$. Similarly, wind delayed irrigation from 34 to 35 DAP in 1991. Cumulative water use $(19.2 \mathrm{~mm})$ exceeded allowable water use $(15.3 \mathrm{~mm})$ by $3.9 \mathrm{~mm}$, and the SWT in the top $30-\mathrm{cm}$ soil profile averaged $59 \mathrm{kPa}$. These data suggest that cumulative water deficit should not exceed allowable water use by more than $3 \mathrm{~mm}$ when allowable water use reaches its maximum. The data also show that the model is accurate, since SWT were $<23$ $\mathrm{kPa}$ at irrigation, and a 1-day delay resulted in $\mathrm{SWT}>25 \mathrm{kPa}$. Irrigation rates $4,5,6$, and 7 resulted in SWT $>25 \mathrm{kPa}$, whereas irrigation rates 1 and 2 resulted in slightly lower SWT. Therefore, the model effectively scheduled irrigation for turnip to meet maximum yield conditions established by Smittle et al. (1992b).

Leaf yield responses to irrigation varied among the four crops and were related to rainfall (Table 2). Although six irrigations were

Table 3. Leaf yields and soil water tension ${ }^{2}$ preceding irrigations of 'Shogoin' turnip in Spring 1990 and 1991.

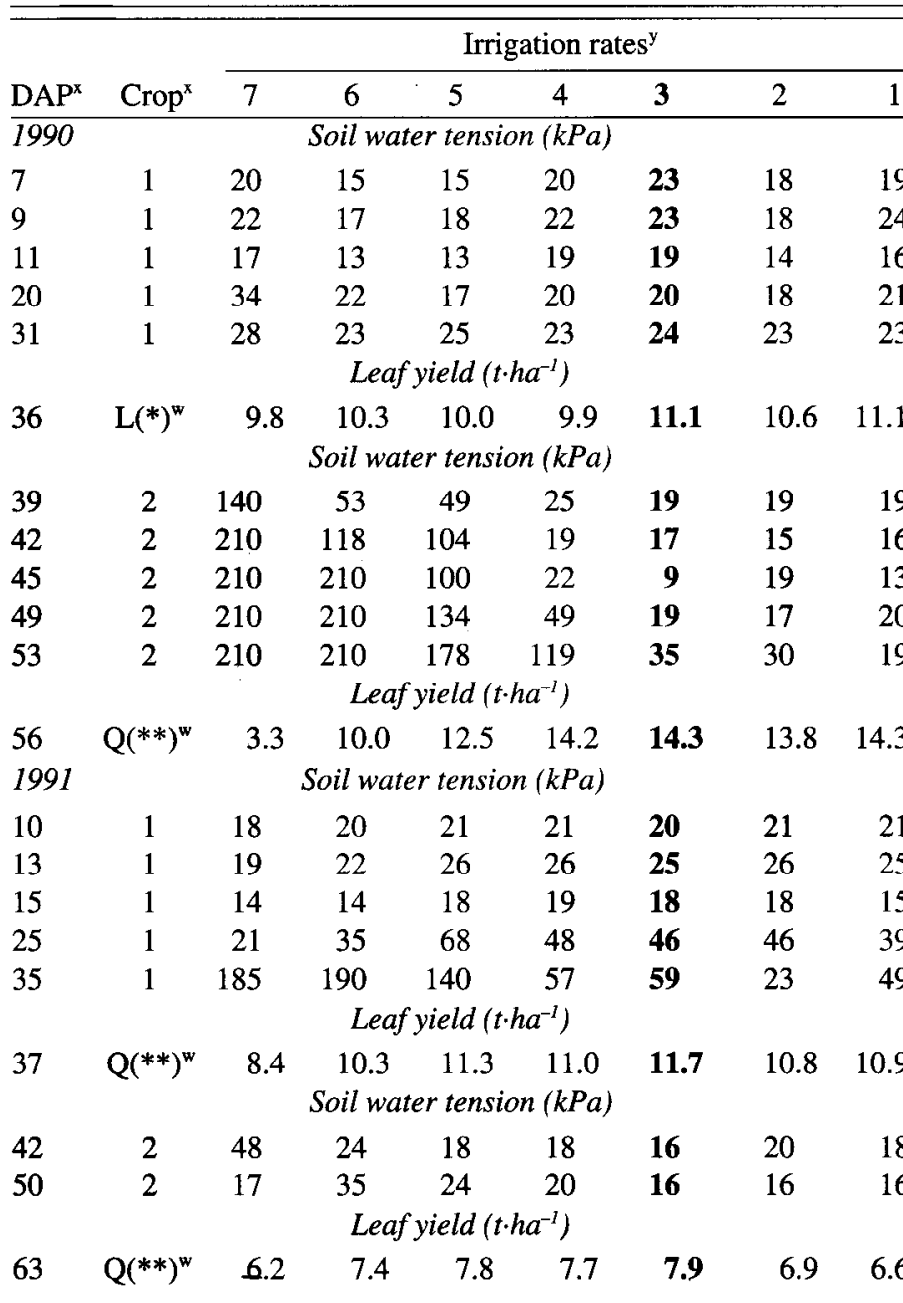

${ }^{\mathrm{z}}$ Averages of soil water tensions at 15 and $30 \mathrm{~cm}$.

yIrrigation rate 3 was determined by the irrigation scheduling model. Rates 2 and 1 represent progressively greater water applications, and rates $4,5,6$, and 7 represent progressively lower water applications by a line-source system (see Table 2 for exact rate for each crop).

${ }^{x}$ Days after planting. Planting dates were 5 Mar. 1990 and 11 Mar. 1991. wYield responses to irrigation Linear (L), or Quadratic (Q) at $P<0.1\left(^{*}\right)$ or $P<0.01(* *)$. applied to crop 1, the combination of rainfall and lateral movement into lower rate plots provided enough water for all plots. Differences in SWT due to irrigation rates were not significant $(P=0.57)$, and leaf yield response to irrigation was linear $\left(R^{2}=0.88, P=0.07\right)$. When irrigation supplied most of the water needs for the turnip, as during crop 2, SWT values were affected significantly by irrigation rates $(P<0.01)$, leaf yield responses to irrigation were quadratic $\left(R^{2}=0.99, P<0.01\right)$, and highest yield occurred at the model rate. Water applications rates higher than irrigation rate 3 did not increase yields whereas water rates lower than irrigation rate 3 restricted yields. Rainfall also supplied a substantial portion of the water requirements during crop 3; however, the rainfall pattern for crop 3 (Fig. 1) resulted in 1) less potential for lateral water movement than occurred for crop 1,2) visible water stress and significantly higher SWT $(P<0.01)$ in plots receiving water rates lower than the model rate, and 3) a quadratic leaf yield response $\left(R^{2}=0.98, P<0.01\right)$ (Table 3$)$. During crop 4, SWT was little affected by irrigation rates $(P=0.11)$. Leaf yields responded quadratically to irrigation rates $\left(R^{2}=0.95, P<0.01\right)$, but $\mathrm{N}$ deficiency symptoms were evident in all plots about 2 weeks before harvest. The lower leaf yields and $\mathrm{N}$ deficiency symptoms of crop 4 were attributed to $\mathrm{N}$ leaching due to excessive rainfall soon after $\mathrm{N}$ application and foliage disease due to frequent foliage wetting (15 times in 26 days).

Leaf yields for crops 1 and 2 increased as $\mathrm{N}$ rates increased $(P$ $<0.01)$. Yield responses to $\mathrm{N}$ applications at $80 \%, 100 \%$, and $120 \%$ of the median recommended rate, respectively, were 9.5 , 10.7, and, $11.0 \mathrm{t} \cdot \mathrm{ha}^{-1}$ for crop 1, and 10.7, 11.4, and $13.1 \mathrm{t} \cdot \mathrm{ha}^{-1}$ for crop 2, respectively. Yield responses to $\mathrm{N}$ rates were similar at all irrigation rates for crop 1 , but a significant $(P=0.02)$ interaction

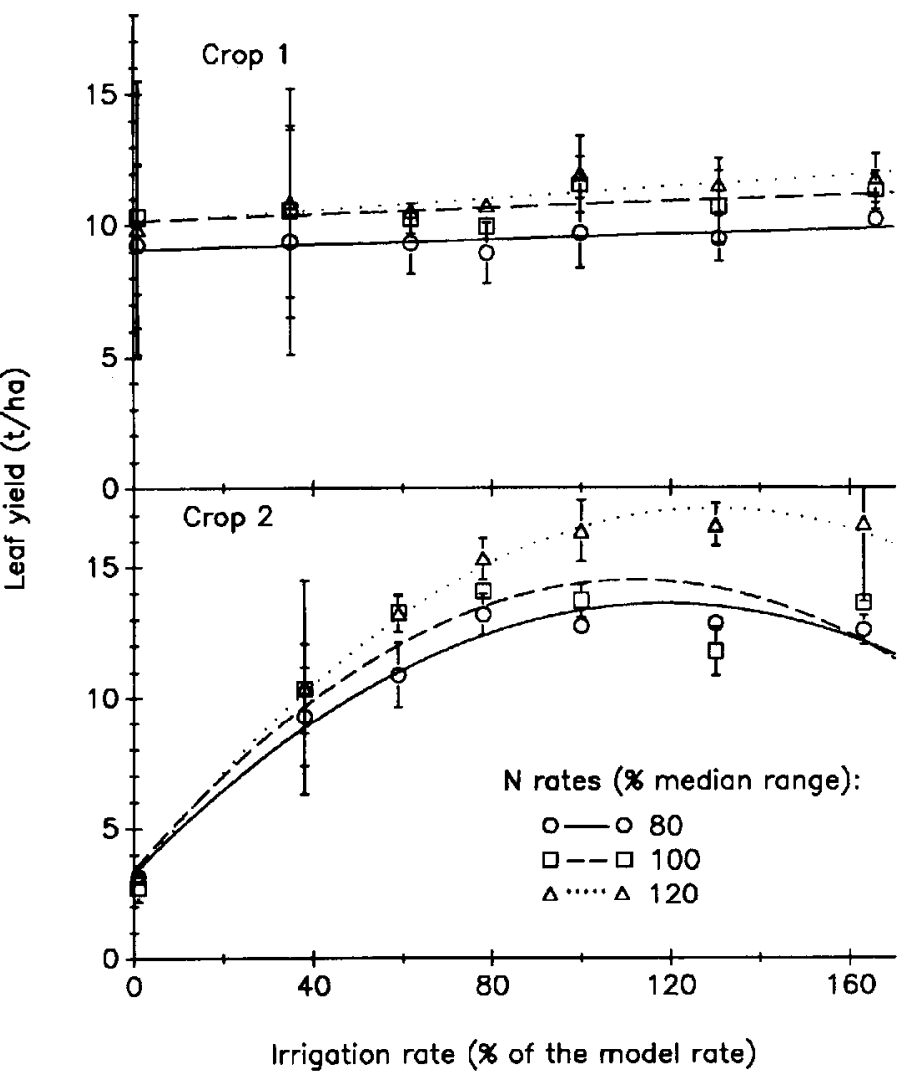

Fig. 2. Turnip leaf yield responses to irrigation and $\mathrm{NaNO}_{3}$ rates at $80 \%$ ( $50 \mathrm{~kg} \mathrm{~N} /$ ha), $100 \%$ (62), and $120 \%$ (73) of the median recommended range for Georgia, for crops 1 and 2. Points and half intervals are means and variance of four observations, respectively. 
between irrigation rate and $\mathrm{N}$ rate for leaf yields occurred for crop 2 (Fig. 2). A combination of high $\mathrm{N}$ rate and adequate moisture resulted in a synergistically increased leaf yield, but did not affect the conclusions of the validation.

In $1991, \mathrm{NaNO}_{3}$ gave significantly $(P<0.01)$ higher yields than the average yield for $\mathrm{Ca}\left(\mathrm{NO}_{3}\right)_{2}$ and $\mathrm{NH}_{4} \mathrm{NO}_{3}$ for crops 3 and 4 . Ammonium nitrate gavehigher yields than $\mathrm{Ca}\left(\mathrm{NO}_{3}\right)_{2}(P=0.06$ and $P<0.01$ for crop 3 and crop 4, respectively). Yield responses to $\mathrm{NaNO}_{3}, \mathrm{Ca}\left(\mathrm{NO}_{3}\right)_{2}$, and $\mathrm{NH}_{4} \mathrm{NO}_{3}$ were, respectively, 12.3, 10.1, and $10.6 \mathrm{t} \cdot \mathrm{ha}^{-1}$ for crop 3, and 8.2, 6.0, and 7.1 th ha ${ }^{-1}$ for crop 4. These results support the current recommendation for $\mathrm{NaNO}_{3}$ as the $\mathrm{N}$ source for turnips in Georgia (Adams, 1991). Whether the beneficial effect of $\mathrm{NaNO}_{3}$ was due to its solubility or to interactions between sodium and potassium or ammonium has not been established.

For crop 3, leaf yields for all $\mathrm{N}$ sources increased with increased irrigation, but turnips with $\mathrm{NaNO}_{3}$ produced higher leaf yield with increased irrigation than those with $\mathrm{Ca}\left(\mathrm{NO}_{3}\right)_{2}$ or $\mathrm{NH}_{4} \mathrm{NO}_{3}$ (Fig. 3).

Under the rainfall conditions of crop 4 that caused soil water deficit to be exceeded repeatedly, leaf yields with $\mathrm{NaNO}_{3}$ or $\mathrm{Ca}\left(\mathrm{NO}_{3}\right)_{2}$ decreased at irrigation rates higher than irrigation rate 4 , but leaf yields with $\mathrm{NH}_{4} \mathrm{NO}_{3}$ continued to increase with higher water application rates (Fig. 3). We attribute the higher leaf yields with $\mathrm{NH}_{4} \mathrm{NO}_{3}$ to the ammonium ion being adsorbed by soil colloids, thereby reducing its leaching rate compared to nitrate.

We have shown that irrigation of turnip grown in the spring could be scheduled with the water balance method, class A pan evaporation, and a crop factor of $0.365+0.0154 \mathrm{i}-0.00011 \mathrm{i}^{2}$, where $\mathrm{i}$ was plant age. Because this model is simple to operate and requires only class $A$ pan evaporation data, it could replace the "feel" or "see" methods to determine the time and amount of irrigation water. The model could be used under most $\mathrm{N}$ fertiliza-

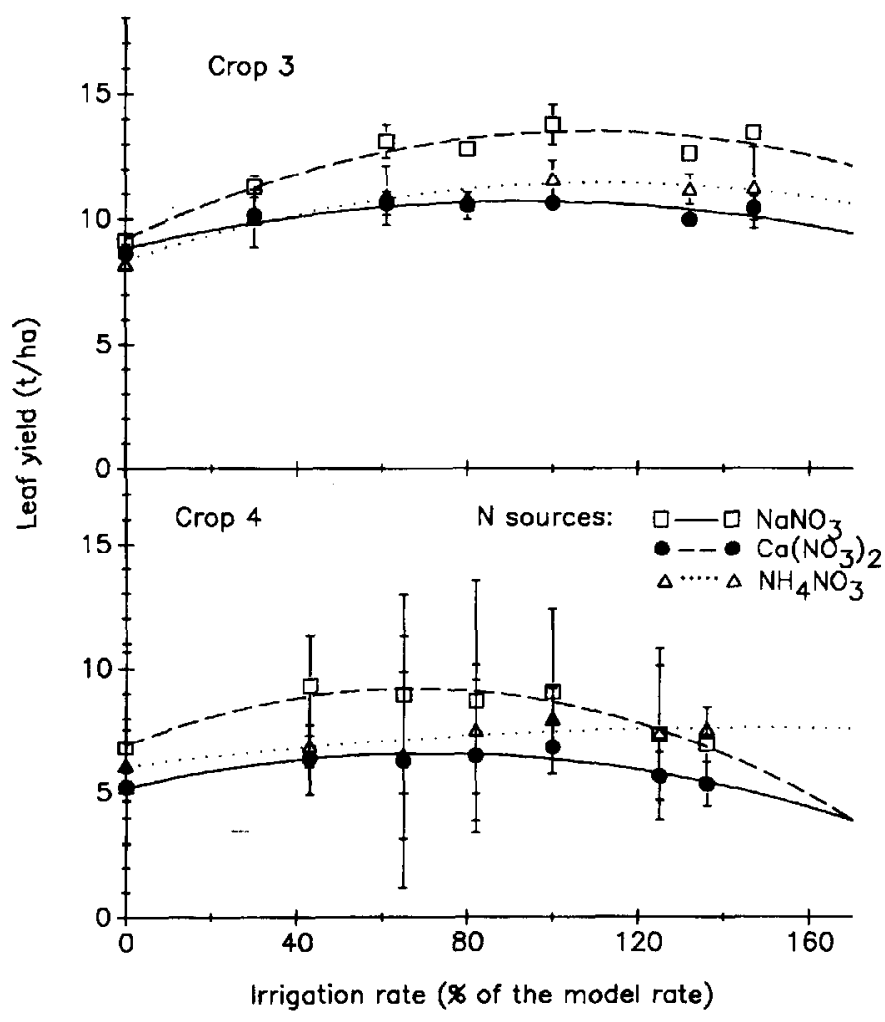

Fig. 3. Turnip leaf yield responses to irrigation and $\mathrm{NaNO}_{3}, \mathrm{Ca}\left(\mathrm{NO}_{3}\right)_{2}$, and $\mathrm{NH}_{4} \mathrm{NO}_{3}$ applied at $100 \%$ of the median recommended $\mathrm{N}$ rate $(62 \mathrm{~kg} \mathrm{~N} / \mathrm{ha})$ for crops 3 and 4. Points and intervals are means and variance of four observations, respectively. tion conditions commonly used in commercial leafy greens production in the southeastern United States.

\section{Literature Cited}

Adams, D. 1991. Commercial cabbage and leafy greens production. Univ. Georgia Coop. Ext. Serv. Bul. 1067.

Barker A.V. and H.A. Mills. 1980. Ammonium and nitrate nutrition of horticultural crops. Hort. Rev. 395-423.

Bowers, J.L. and H.H. Vose. 1959. Nitrogen fertilization of turnip greens. Ark. Farm Res. 8(6):11.

Bowers, J.L., H.H. Vose, and J. McFerran. 1962. Turnip greens and spinach: Cultural and fertilizer studies. Univ. Arkansas Agr. Exp. Sta. Bul. 654

Brantley, B.B. 1960. Effect of source and level of nitrogen on the yield and nitrogen content of turnip greens. Georgia Exp. Sta. J. Ser. Bul. 388.

Breimer, T. 1983. Environmental factors and cultural measures affecting the nitrate content in spinach. Nijhoff and Junk, Landbouwhogeschool, Wageningen, The Netherlands.

Brown, E.A. 1989. Georgia pest control handbook. Univ. Georgia Coop. Ext. Serv., Athens, Ga.

del Valle, C.G. and S.A. Harmon. 1970. Influence of seeding rate, source and level of nitrogen on yield, color, leaf blade weight and nitrogen content of turnip greens. J. Amer. Soc. Hort. Sci. 95:62-64.

del Valle, C.G., S.A. Hamon, and R.E. Worley. 1965. Effect of fertilizer rates and moisture levels on turnip greens production. Ga. Agr. Res. $7(2): 2-5$

Hanks, R.J, J. Keller, V.P. Rasmussen, and G.D. Wilson. 1976. Line source sprinkler for continuous variable irrigation-crop production studies. Soil Sci. Soc. Amer. J. 40:426-429.

Hansen, V.E., O.W. Israelsen, and G.E. Stringham. 1980. Irrigation principles and practices. 4th ed. Wiley, New York.

Jensen, M.C. and J.E. Middleton. 1970. Scheduling irrigation from pan evaporation Washington Agr. Expt. Sta. Circ. 527.

McFerran, J., J.L. Bowers, and H.H. Vose. 1963. Effect of seeding rate and nitrogen level on color and yield of turnip greens. Ark. Farm Res. 12(5): 11

McSay, A.E. and F.D. Moore. 1980. A model for scheduling lettuce irrigation. Colorado State Univ. Expt. Sta. Tech. Bul. 141.

Nieuwhof, M. 1969. Cole crops. CRC Press, Cleveland.

Plank, C.O. 1989. Soil test handbook for Georgia. Univ. Georgia Coop. Ext. Serv., Athens, Ga.

Salunkhe, D.K., S.K. Pao, and G.G. Dull. 1973. Assessment of nutritive value, quality and stability of cruciferous vegetables during storage and subsequent to processing. Critical Rev. Food Technol. 4(1):1-37.

SAS. 1987. STAT guide for personal computers. SAS Institute, Cary, N.C.

Smittle, D.A. and W.L. Dickens. 1992. Water budgets to schedule irrigation of vegetables. HortTechnology 2:54-59.

Smittle, D.A., W.L. Dickens, and J.R. Stansell. 1990. An irrigation scheduling model for snap bean. J. Amer. Soc. Hort. Sci. 115:226-230.

Smittle, D.A., W.L. Dickens, and M.J. Hayes. 1992a. An irrigation scheduling model for summer squash. J. Amer. Soc. Hort. Sci. 117:717720.

Smittle, D.A., W.L. Dickens, J.R. Stansell, and E. Simonne. 1992b. Effects of irrigation regimes on leaf yield and water use by turnip and mustard. HortScience 27:308-310

Stansell. J.R. and D.A. Smittle. 1980. Effect of irrigation regimes on yield and water use of snap bean (Phaseolus vulgaris L.). J. Amer. Soc. Hort. Sci. 105:869-873.

Stegeman, E.C., J.R. Musick, and J.I. Steward. 1980. Irrigation water management, p. 763-816. In: M.E. Jensen (ed.). Design and operation of farm irrigation systems. Amer. Soc. Agr. Eng., St. Joseph, Mich.

Tan, K.H. 1982. Principles of soil chemistry. Dekker, New York. 